\title{
Ligula intestinalis (Cestoda: Pseudophyllidea): phosphorylcholine inhibition of fish leucocyte adherence
}

\author{
D. Hoole, C. Arme \\ Parasitology Research Laboratory, University of Keele, Keele, Staffordshire ST5 5BG, England
}

\begin{abstract}
The effect of phosphorylcholine (PC) on serum mediated adherence of fish leucocytes to the plerocercoid of Ligula intestinalis has been investigated. Parasites removed from the body cavity of naturally infected roach (Rutilus rutilus) fry were cultured for $24 \mathrm{~h}$ in Leibovitz medium and then exposed in vitro to leucocytes obtained from the pronephros of healthy roach and either untreated or PC-treated normal roach serum or immune roach serum. Ultrastructural observations revealed that the addition of PC to serum reduced leucocyte adherence; however, this was only significant in assays containing treated normal roach serum. In all assays macrophages, neutrophils and lymphocytes were present on the parasite surface, and phagocytosis of the microtriches by the former 2 cell types occurred. It is suggested that the acute phase protein. CRP, perhaps in association with complement, is involved in the adherence of fish leucocytes to metacestodes.
\end{abstract}

\section{INTRODUCTION}

Phosphorylcholine is found in many organisms including some parasitic helminths (e.g. Pery et al 1974, Gutman \& Mitchell 1977, Fried \& Shapiro 1979) In pseudophyllidean cestodes, Sugane \& Oshima (1983) noted the presence of phosphorylcholine (PC) in extracts of adult Diphyllobothrium latum from humans and Fletcher et al. (1980) isolated a phosphorylcholinecontaining component from the adult stage of the turbot tapeworm Bothriocephalus scorpii. There have been several reports (e.g. Gualzata et al. 1986) indicating that phosphorylcholine haptenic groups in helminths induce the production of anti-phosphorylcholine antibodies. In addition, phosphorylcholine has been found to be a major receptor for the acute phase protein, C-reactive protein (Gotschlich et al. 1982). Both types of complex formed, i.e. antigen/antibody or phosphorylcholine/C-reactive protein, are known to induce complement activation via the classical pathway. Indeed, Sugane \& Oshima (1983) have suggested that a phosphorylcholine-bearing component from Toxocara canis might react with $\mathrm{C}$-reactive protein and, through the complement system, induce an inflammatory response.

The plerocercoid of Ligula intestinalis, which occurs in the body cavity of various species of cyprinid fish, has been associated with an intense cellular response. Ultrastructural observations (Hoole \& Arme 1982, 1983) revealed that in roach Rutilus rutilus 3 leucocyte types, i.e. lymphocytes, L1 cells (macrophages?) and L2 cells (neutrophils?), predominate. In vitro studies (Hoole \& Arme 1986) suggest that the adherence of roach leucocytes to the metacestode of $L$. intestinalis may be mediated by serum components including complement. To investigate the role of phosphorylcholine in fish leucocyte attachment to helminths, inhibition studies have been carried out in which phosphorylcholine-treated serum is incorporated into an in vitro cell adherence assay.

\section{MATERIALS AND METHODS}

Fish. Non-infected and ligulosed roach Rutilus rutilus, fork length 9.5 to $13.5 \mathrm{~cm}$, were collected from Blithfield Reservoir, Staffordshire and Highfield Pool, Nottinghamshire (England). Ligulosed fry, ca 4 to 6 mo of age, were obtained from the former location. All fish were kept in aerated dechlorinated tap water $\left(14{ }^{\circ} \mathrm{C} \pm 1 \mathrm{C}^{\circ}\right)$ and fed on commercial fish meal.

Parasites. Infected roach fry were dissected under teleost Ringer (Lockwood 1963). Plerocercoids (1 to $1.5 \mathrm{~cm}$ in length) were removed from the body cavity 
Table 1. Adherence of roach leucocytes to the plerocercoid of Ligula intestinalis. Percentages of parasite surface covered with cells $\pm \mathrm{SE}_{i} n$ in brackets

\begin{tabular}{|c|c|c|c|c|c|}
\hline \multirow{2}{*}{$\begin{array}{l}\text { Phosphorylcholine } \\
\text { ( } 2 \mathrm{mM} \text { ) }\end{array}$} & \multirow[t]{2}{*}{ No serum } & \multicolumn{2}{|c|}{1100 dilution NRoS } & \multicolumn{2}{|c|}{$1: 100$ dilution hiIRos } \\
\hline & & - phosphorylcholine & $\begin{array}{c}+ \text { phosphorylcholine } \\
(0.2 \mathrm{M})\end{array}$ & - phosphorylcholine & $\begin{array}{c}+ \text { phosphorylcholine } \\
(0.2 \mathrm{M})\end{array}$ \\
\hline $\begin{array}{c}9.3 \pm 3.1 \\
(3)\end{array}$ & $\begin{array}{c}16.1 \pm 2.5 \\
(6)\end{array}$ & $\begin{array}{c}\cdot 31.1 \pm 3.7 \\
(7)\end{array}$ & $\begin{array}{c}\cdot 13.1 \pm 3.7 \\
(6)\end{array}$ & $\begin{array}{c}27.3 \pm 5.2 \\
(5)\end{array}$ & $\begin{array}{c}19.2 \pm 3.3 \\
(9\}\end{array}$ \\
\hline
\end{tabular}

using parafilm-coated forceps, and placed immediately into Leibovitz' culture medium on ice (Hoole \& Arme 1985). After donor host cells had been removed by vigorous agitation, intact parasites, as judged by light microscopical observations, were cultured for $24 \mathrm{~h}$ at $15^{\circ} \mathrm{C}$ in Leibovitz' medium (Hoole \& Arme 1985).

Leucocytes. A leucoctye suspension was obtained from the pronephros of non-infected roach as previously described (Hoole \& Arme 1986).

Serum. Blood collected from non-infected and ligulosed roach by caudal puncture was allowed to clot for 1 to $1.5 \mathrm{~h}$ at $4{ }^{\circ} \mathrm{C}$ and the serum removed after centrifugation at $1500 \times g$ for $15 \mathrm{~min}$ at $4{ }^{\circ} \mathrm{C}$. The complement component in the serum from infected fish (immune serum) was inactivated by heating at $48^{\circ} \mathrm{C}$ for $20 \mathrm{~min}$ (Hoole \& Arme unpubl.) and $0.2 \mathrm{M}$ phosphorylcholine (Sigma) was added to some aliquots. All serum was stored at $4{ }^{\circ} \mathrm{C}$ for 30 min until required.

Adherence assay. A single, intact, cultured plerocercoid was placed in each well of a Linbro 24 -well culture plate (Flow Laboratories) containing $1 \mathrm{ml}$ of modified Leibovitz' medium. To each well was added a leucocyte suspension containing $4 \times 10^{6}$ cells and a $1: 100$ dilution of normal roach serum (NRoS) or heat inactivated serum from ligulosed fish (hilRoS), some aliquots of which had been phosphorylcholine-treated. Controls lacking serum and/or cells were also included. In addition, some parasites were exposed to $2 \mathrm{mM}$ phosphorylcholine alone or with cells. Cultures were maintained in air at $15^{\circ} \mathrm{C}$. After $24 \mathrm{~h}$ parasites and adherent cells were processed for electron microscopy and the \% cell cover determined using scanning electron microscopy as previously described (Hoole \& Arme 1986).

\section{RESULTS}

Scanning electron microscopical observations on parasites which had been removed from the body cavity of roach and then agitated and cultured revealed that very few donor host leucocytes remained on the surface of the metacestode ( $\%$ cell cover $0.84 \pm 0.24$ ). The adherence of roach leucocytes in the presence and absence of phosphorylcholine is shown in Table 1. Very few cells attached to the plerocercoid in the presence of phosphorylcholine alone or in the absence of serum. The addition of phosphorylcholine to heat-inactivated immune serum reduced the leucocyte adherence to the parasite; however, statistical analysis revealed that this reduction was not significant. In contrast, phosphorylcholine treatment of normal roach serum significantly reduced leucocyte adherence, a $58 \%$ decrease in \% cell cover being observed.

Transmission electron microscopical observations on the tegument of the plerocercoid of Ligula intestinalis have been described by Charles \& Orr (1968), Threadgold \& Hopkins (1981) and Hoole \& Arme (1985). Briefly, the parasite is covered by a typical cestode tegument comprising cytons and distal cytoplasm which contain secretory bodies with an extensive microthrix border $12 \mu \mathrm{m}$ thick. Ultrastructural observations revealed that phosphorylcholine had no detectable deleterious effects on the parasite tegument (Fig. 1). In all treatments containing a leucocyte suspension, macrophages, neutrophils and lymphocytes occurred on the surface of the metacestode (Fig. 2). There was no obvious difference in the ultrastructural appearance of the different leucocyte types present in any of the

Figs. 1 to 6. Ligula intestinalis. Fig. 1. Plerocercoid exposed to phosphorylcholine. Distal cytoplasm (D), which appears 'normal', contains electron-dense secretory bodies $(S)$ and an extensive microthrix border $(B) ;(\times 4500)$. Fig. 2 . Plerocercoid incubated in hilRoS and leucocytes. Macrophages (M), neutrophils $(N)$ and lymphocytes (L) occur on the parasite surface. Note phagocytic vesicles in macrophages (arrow) and penetration of lymphocytes into microthrix border (B); ( $\times$ 3800). Fig. 3. Neutrophil (N) containing phagocytosed portions of microtriches (arrow); ( $\times 12000)$. Fig. 4. Plerocercoid incubated in NRoS and leucocytes. Neutrophils (N) penetrating the microthrix border (B). Note cell on left is adjacent to the intra-microthrix membrane (arrow); ( $X$ 7500). Fig. 5. Plerocercoid incubated in hilRoS, phosphorylcholine and leucocytes. Neutrophil (N) spreading over the surface of the parasite (P). Note presence of long pseudopodial extension (arrow); $(\times 8700)$. Fig. 6. Scanning electron micrograph of parasite incubated in leucocytes, hilRoS and phosphorylcholine. Leucocytes (arrow) occur on the surface of the plerocercoid and areas denuded of microtriches are present $(A)_{i}(\times 250)$ 

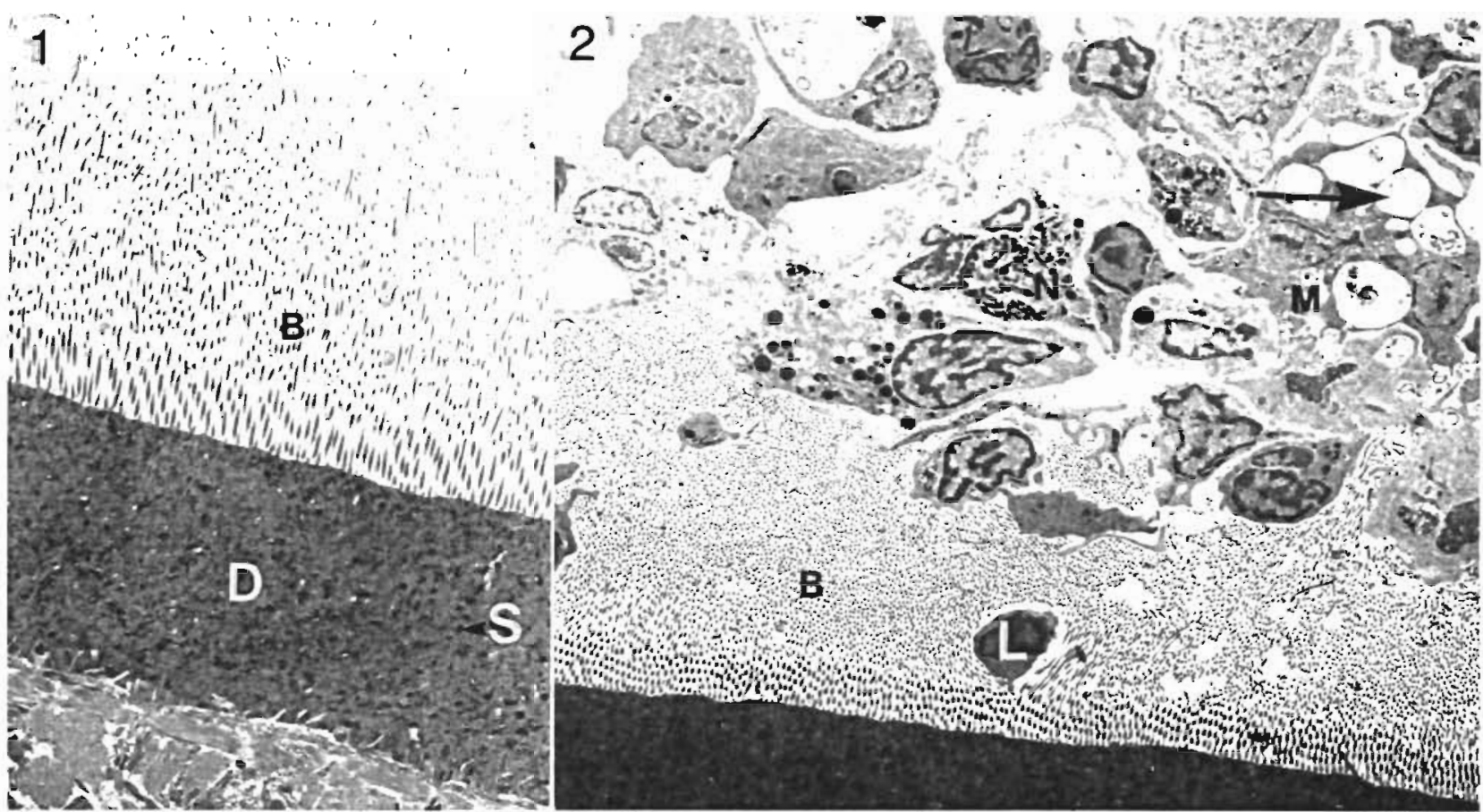

3

S.
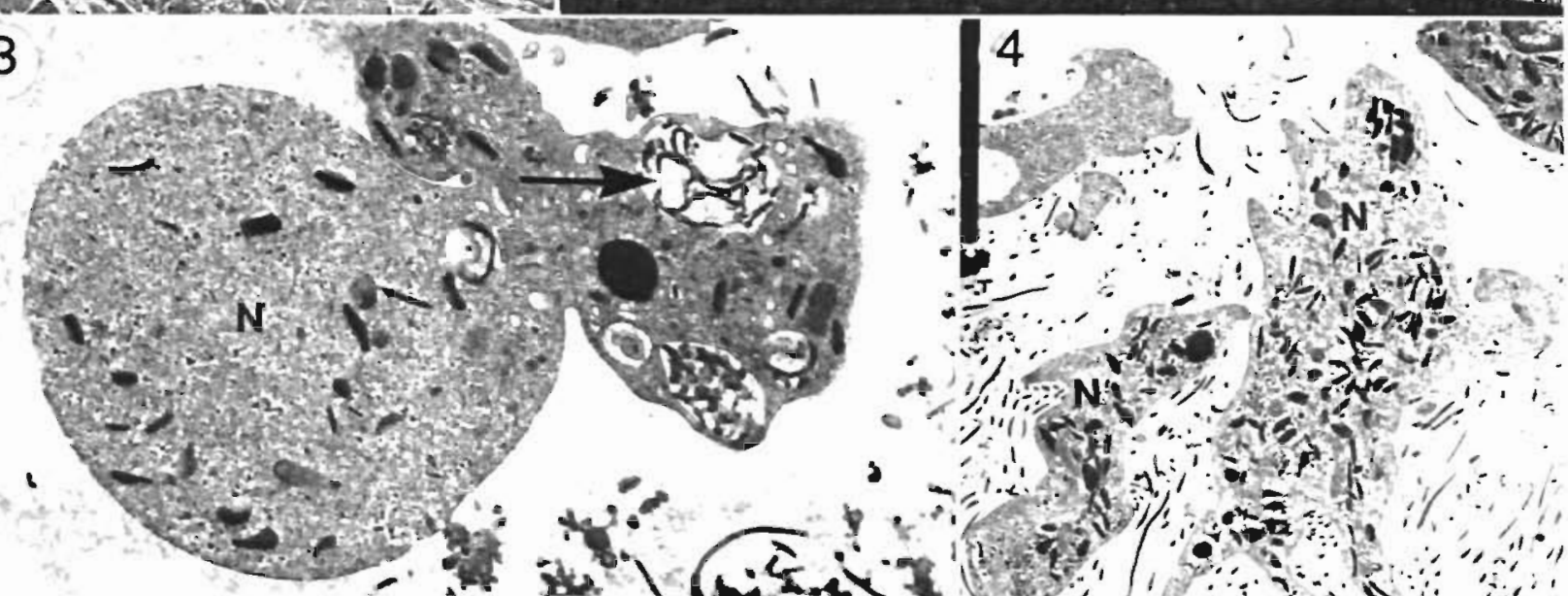

(t)

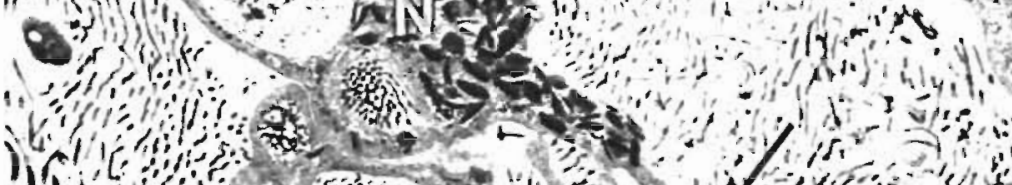

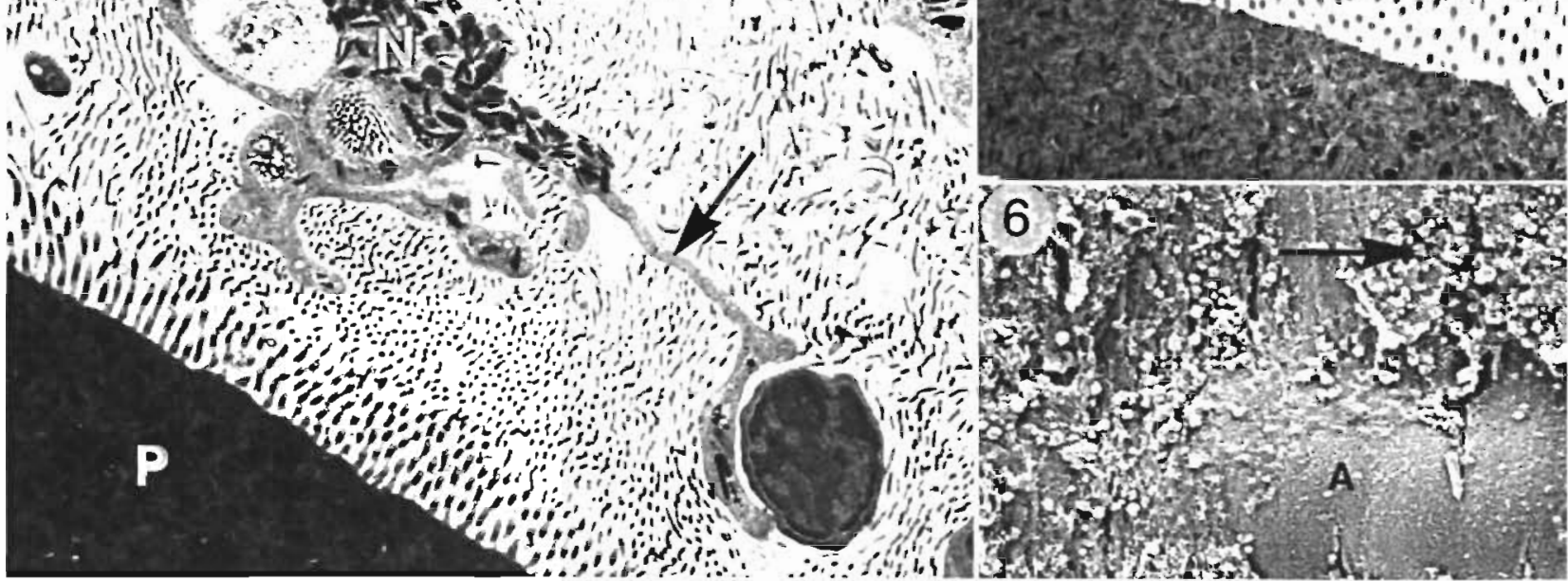


assays carried out. In all treatments, even those lacking serum, phagocytic vesicles, some containing portions of microthrix spinos, were found in neutrophils, and/or monocytes/macrophages (Fig. 3). In some areas of the parasite, cell penetration into the microthrix border was observed; however, the migration of leucocytes appeared to be impeded by the microthrix shaft and only occasionally, usually in treatments containing hilRoS or untreated NRoS, were leucocytes, particularly neutrophils, found adjacent to the intra-microthrix membrane (Fig. 4). The majority of the leucocytes, some of which formed long pseudopodial extensions up to $6 \mu \mathrm{m}$ in length, occurred distal to the microthrix shaft (Fig. 5). Some parasites in all treatments contained areas in which microtriches were absent. In assays comprising only cells and L-15 medium, such regions were small. However, in some metacestodes exposed to cells and either untreated or treated hilRos, extensive areas of microthrix denudation occurred (Fig. 6).

\section{DISCUSSION}

Leucocytes isolated from the pronephros of Rutilus rutilus attach to the plerocercoid of Ligula intestinalis in vitro. Results partially confirm the original observations of Hoole \& Arme (1986) which indicate that fish leucocyte adherence to a metazoan parasite may involve some serum component. However, in contrast to our previous observations, the percentage cell cover is low in assays containing serum. This variability may be a result of using fish obtained from the wild, e.g. the $27.3 \%$ cell cover in assays containing hilRoS cf $67.8 \%$ (Hoole \& Arme 1986) may reflect the different levels of antibody in the 2 populations of fish used. Whether ligulosis induces a humoral response in cyprinid fish has not been clearly established. Molnár \& Berczi (1965) found specific antibodies in the serum of ligulosed bream Abramis brama, and Sweeting (1977) detected an increase in $\gamma$ globulin in ligulosed roach, although he failed to detect precipitating antibodies.

The presence of phosphorylcholine reduces the percentage cell cover of serum-mediated leucocyte attachment. Unfortunately, we are not able to establish if the effect of phosphorylcholine is mediated through binding with an anti-phosphorylcholine antibody or C-reactive protein. However, the concentration of phosphorylcholine used is greater than that utilized by other workers to inhibit C-polysaccharide/CRP precipitation (Winkelhake \& Chang 1982), to cause the disappearance of precipitate lines between plaice serum and human CRP and extracts of pneumococcus, fungi and Ascaris (Baldo \& Fletcher 1973) and to inhibit the combined effects of lumpsucker CRP and phytohaemagglutin on mouse spleen cells (Fletcher et al. 1980). Prelimi- nary investigations using radial immunodiffusion plates containing antibody against human CRP revealed that pre-treating cyprinid serum with $0.2 \mathrm{M}$ phosphorylcholine reduces the precipitate formed (Hoole \& Arme unpubl.).

In contrast to assays containing normal roach serum, the reduction in percentage cell cover in assays with heat-inactivated immune roach serum is not significant. This may result from the presence of antibodies in the serum that, whilst reacting with Ligula intestinalis, do not interact with phosphorylcholine. Although the presence of natural antibodies to PC in non-ligulosed fish cannot be excluded, it is more likely that the significant reduction caused by treating normal roach serum with phosphorylcholine results from the binding of PC to CRP. Proteins anaiogous to the mammalian Creactive protein have been found in a variety of fish species, e.g. plaice Pleuronectes platessa, lumpsucker Cyclopterus lumpus, tilapia Tilapia mossambica, and rainbow trout Salmo gairdneri. Mammalian CRP is an acute-phase protein that increases in concentration several thousand times after infection or trauma. Baldo \& Fletcher (1973) suggested that, since CRP-like precipitins were present in apparently healthy 'normal' $P$. platessa, this protein was a normal constituent of plaice serum. Subsequently, White et al. (1983) found that there was a seasonal variation in serum concentration of this protein in plaice, and Winkelhake \& Chang (1982) observed that acute chemical and physical stresses increased levels of CRP in $S$. gairdneri. Human CRP can activate the classical complement pathway via $\mathrm{CI}$ activation just as efficiently as IgG antibody with the generation of C-dependent activities, e.g. adherence, phagocytosis and lysis (for review see Gewurz et al. 1982, Volanakis 1982, Pepys \& Baltz 1983). Sugane \& Oshima (1983) observed that a phosphorylcholine bearing component from Toxocara canis larvae induced complement consumption via the classical pathway in CRP positive serum. They suggested that this activation of complement may trigger leucocyte chemotactic responses and complement mediated phagocytosis in parasitized individuals. Such phenomena may occur in our assays containing Ligula and normal roach serum. Complexed or aggregated mammalian CRP induces phagocytosis by granulocytes and monocytes, binds to the Fc receptor of lymphocytes and alters some of their functions, affects platelet function and is involved in the natural killer cell response (Gewurz et al. 1982, James et al. 1982, Baum et al. 1983, Pepys \& Baltz 1983). The effects of fish CRP on fish leucocytes has not been extensively studied. Fletcher et al. (1980) noted that lumpsucker CRP significantly stimulate blood leucocytes of plaice but not lumpsucker at $20^{\circ} \mathrm{C}$, and an immediate (Type l) hypersensitivity skin reaction, thought to involve CRP, 
was observed in several flatfish species after injection of fungal extracts (Fletcher \& Baldo 1974). Although electron microscopical observations on $L$. intestinalis in the in vitro assays revealed differences between treatments in the number of cells attached to the parasite, marked differences in the ultrastructural appearance of the cells were not observed.

In conclusion, our results suggest that a non-specific serum component may be involved in the adherence of roach leucocytes to the metacestode of Ligula intestinalis. Since the action of this component appears to be inhibited by phosphorylcholine, it may be CRP. Such a non-specific cell-mediated response may be particularly important at low temperatures where fish antibody production is often decreased.

\section{LITERATURE CITED}

Baido, B. A., Fletcher, T C. (1973). C-reactive protein-like precipitations in plaice. Nature, Lond. 246: 145-146

Baum, L. L., James, K. K., Glaviano, R. R., Gewurz, H. (1983). Possible role for C-reactive protein in the human natural killer cell response. J. exp. Med. 157: 301-311

Charles, G. H., Orr, T. S. C. (1968). Comparative fine structure of the outer tegument of Ligula intestinalis and Schistocephalus solidus. Expl Parasit. 22: 137-149

Fletcher, T C., Baldo, B. A. (1974). Immediate hypersensitivity responses in flatfish. Science 185: 360-361

Fletcher, T C., Thomson, A. W., Baldo, B. A. (1980). Effect of lumpsucker (Cyclopterus lumpus L.) C-reactive protein on DNA synthesis in cultured and marine leucocytes. Comp. Biochem. Physiol. 67B: 127-131

Fletcher, T C., White, A., Baldo, B. A. (1980). Isolation of a phosphorylcholine-containing component from the turbot tapeworm, Bothriocephalus scorpii (Müller), and its reaction with C-reactive protein. Parasite Immunol. 2: 237-248

Fried, B., Shapıro, I. L. (1979). Thin-layer chromatographic analysis of phospholipids in Echinostoma revolutum (Trematoda) adults. J. Parasitol. 65: 243-245

Gewurz, H., Mold, C., Siegel, J., Fiedel, B. (1982). C-reactive protein and the acute phase response. Adv. Int. Med. 27 : 345-372

Gotschlich, E. C., Liu, T. Y., Oliveira, E. (1982). Binding of Creactive protein to $\mathrm{C}$ carbohydrate and $\mathrm{PC}$-substituted protein. Ann. N.Y Acad. Sci. 389: 163-169

Gualzata, M., Weiss, N., Heasser, Ch. H. (1986). Dipetalonema viteae: phosphorylcholine and non-phosphorylcholine antigenic determinants in infective larvae and adult worms. Expl Parasit. 61: 95-102
Gutman, G. A., Mitchell, G. F. (1977). Ascaris suum: location of phosphorylcholine in lung larvae. Expl Parasit. 43: 161-168

Hoole, D., Arme, C. (1982). Ultrastructural studies on the cellular response of roach, Rutilus rutilus L., to the plerocercoid larva of the pseudophyllidean cestode, Ligula intestinalis. J. Fish Dis. 5: 131-144

Hoole, D., Arme, C. (1983). Ligula intestinalis (Cestoda: Pseudophyllidea): an ultrastructural study on the cellular response of roach fry, Rutilus rutilus. Int. J. Parasit. 13: 359-363

Hoole, D., Arme, C. (1985). The in vitro culture and tegumental dynamics of the plerocercoid of Ligula intestinalis (Cestoda Pseudophyllidea). Int. J. Parasit. 15: 606-615

Hoole, D., Arme, C. (1986). The role of serum in leucocyte adherence to the plerocercoid of Ligula intestinalis (Cestoda. Pseudophyllidea). Parasitology 92: 413-424

James, K., Baum, L. L., Vetter, M. L., Gewurz, H. (1982). Interactions of C-reactive protein with lymphoid cells. Ann. N.Y Acad. Sci. 389: 274-285

Lockwood, A. P. M. (1963). Animal body fluids and their regulation. Heinemann, London

Molnár, K., Berczi, I. (1965). Nachweis von parasitenspezifischen Antikörpern im Fischblut mittels der Agar-GelPräzipitationsprobe. Z. ImmunForsch. exp. Ther 129: 263-267

Pepys, M. B., Baltz, M. L. (1983). Acute phase proteins with special reference to $C$-reactive protein and related proteins (pentaxins) and serum amyloid A protein. Adv. Immun. 34: $141-212$

Pery, P., Petit, A., Poulain, J., Laffau, G. (1974). Phosphorylcholine-bearing components in homogenates of nematodes. Eur. J. Immunol. 4: 637-639

Sugane, K, Oshima, T. (1983). Activation of complement in Creactive protein positive sera by phosphorylcholine-bearing component isolated from parasite extract. Parasite Immunol. 5: 385-395

Sweeting, R. A. (1977). Studies on Ligula intestinalis: some aspects of the pathology in the second intermediate host. J. Fish Biol. 10: 43-50

Threadgold, L. T., Hopkins, C. A. (1981). Schistocephalus solidus and Ligula intestinalis: pinocytosis by the tegument. Expl Parasit. 51. 444-456

Volanakis, J. E. (1982). Complement activation by C-reactive protein complexes. Ann. N.Y Acad. Sci. 389: 235-249

White, A, Fletcher, T. C.. Pepys, M. B. (1983). Serum concentrations of $\mathrm{C}$-reactive protein and serum amyloid $\mathrm{P}$ component in plaice (Pleuronectes platessa L.) in relation to season and injected lipopolysaccharide. Comp. Biochem. Physiol. 74B: 453-458

Winkelhake, J. L., Chang, R. J. (1982). Acute phase (C-reactive) protein-like macromolecules from rainbow trout (Salmo gairdneri). Dev. Comp. Immun. 6: 481-489 